Provided for non-commercial research and education use. Not for reproduction, distribution or commercial use.

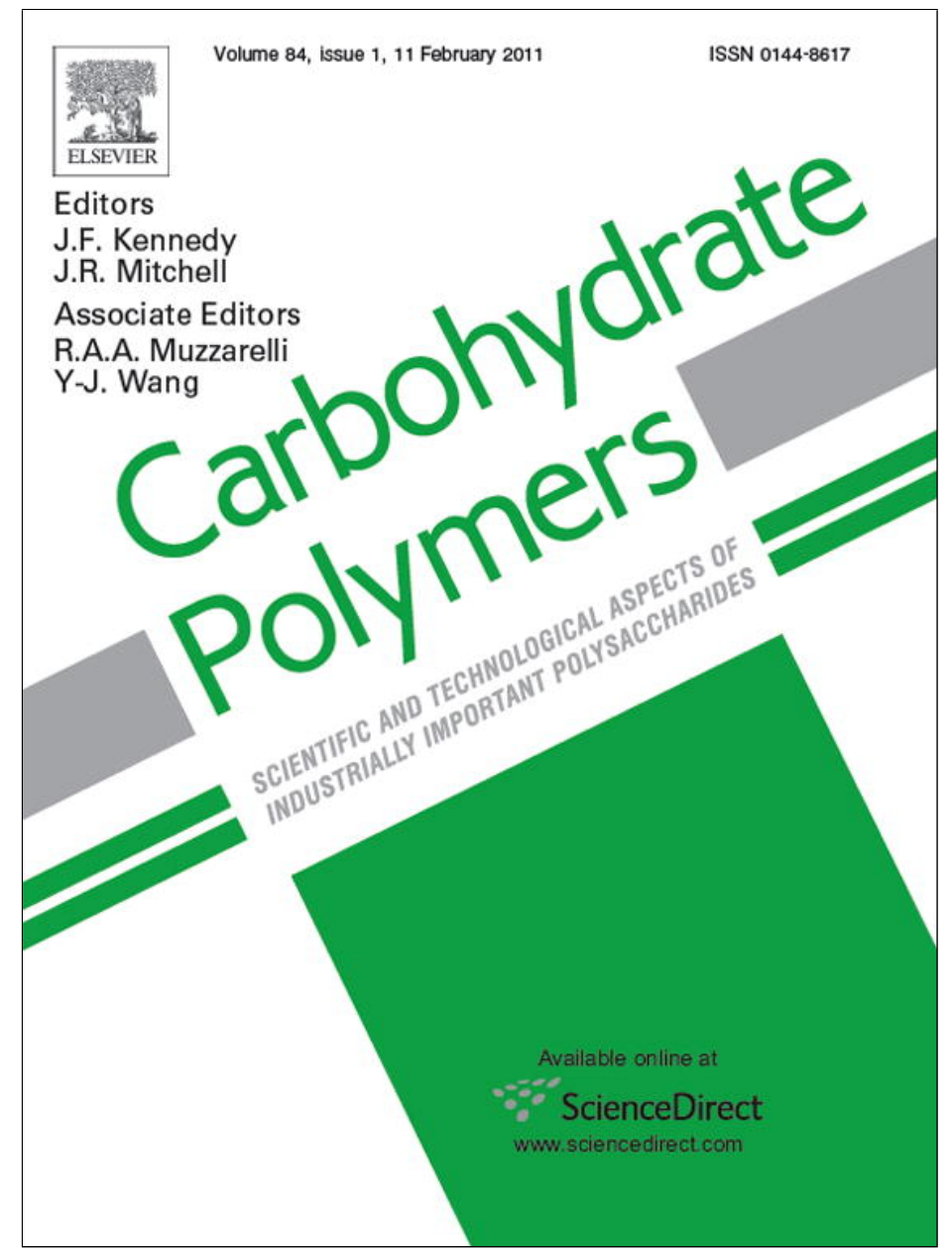

This article appeared in a journal published by Elsevier. The attached copy is furnished to the author for internal non-commercial research and education use, including for instruction at the authors institution and sharing with colleagues.

Other uses, including reproduction and distribution, or selling or licensing copies, or posting to personal, institutional or third party websites are prohibited.

In most cases authors are permitted to post their version of the article (e.g. in Word or Tex form) to their personal website or institutional repository. Authors requiring further information regarding Elsevier's archiving and manuscript policies are encouraged to visit:

http://www.elsevier.com/copyright 


\title{
Portuguese carrageenophytes: Carrageenan composition and geographic distribution of eight species (Gigartinales, Rhodophyta)
}

\author{
Leonel Pereira ${ }^{\mathrm{a}, *}$, Fred van de Velde ${ }^{\mathrm{b}, \mathrm{c}}$ \\ a IMAR (Institute of Marine Research), Department of Life Sciences, Faculty of Sciences and Technology, University of Coimbra, Apartado 3046, 3001-401 Coimbra, Portugal \\ ${ }^{b}$ TI Food E Nutrition, P.O. Box 557, 6700 AN Wageningen, The Netherlands \\ ${ }^{\mathrm{c}}$ NIZO food research, Kernhemseweg 2, P.O. Box 20,6710 BA Ede, The Netherlands
}

\section{A R T I C L E I N F O}

\section{Article history:}

Received 26 May 2010

Received in revised form

11 December 2010

Accepted 13 December 2010

Available online 21 December 2010

\section{Keywords:}

Carrageenophytes

Gigartinales

Seaweed

Portugal

Carrageenan

${ }^{1} \mathrm{H}$ NMR

\begin{abstract}
A B S T R A C T
Eight carrageenophytes from the Centre and North coast of Portugal, representing seven genera and three families of Gigartinales, were studied in 15 different coastal stations in a geographic study, from Baleal (Peniche), in the central zone, to Moledo, in the northern zone.

In order to characterize the different carrageenan types, ${ }^{1} \mathrm{H}$ NMR spectroscopy was used to identify and quantify the different carrageenan fractions in the extracted phycocolloids (both water and alkali extractions). Thereby, detailed information concerning the properties and structure of these polysaccharides at molecular level was revealed.

Based on the results of the analysis of the carrageenan types, the following conclusions were made: female gametophytes and non-fertile thalli of Chondrus crispus, Mastocarpus stellatus, Chondracanthus teedei var. lusitanicus, Gigartina pistillata, Chondracanthus acicularis and Gymnogongrus crenulatus, presented a varying degrees of kappa-iota hybrid carrageenan (co-polymers of kappa-iota carrageenan). The kappa/iota ratio ranged from 0 to 2.2. The carrageenans extracted from Ahnfeltiopsis devoniensis were mainly iota-carrageenan, but some geographic variations in the composition of carrageenans were found. Calliblepharis jubata contained carrageenans of iota-type in all reproductive stages. Lambda-family carrageenans were found in tetrasporophytes of $C$. cripus (lambda), M. stellatus (lambda), C. teedei var. lusitanicus (hybrid xi-theta), C. acicularis (hybrid xi-theta) and G. pistillata (hybrid xi-lambda).
\end{abstract}

(c) 2010 Elsevier Ltd. All rights reserved.

\section{Introduction}

The coast of mainland Portugal is approximately $830 \mathrm{~km}$ long, with rocky regions separated by sandy beaches, which are often large in size. Most of the beaches are very exposed (after Lewis, 1964) and intertidal algae are mainly found closest to the low tide level (Múrias, 1994). With regard to seaweed biogeography, Portugal is situated in the warm temperate Mediterranean-Atlantic region: continental Portugal falls in the Lusitania Province.

Today, the main references on Portuguese algae are the publications of Palminha (1951, 1971), Santos and Duarte (1991) and Melo (1998), which are mainly concerned with the agarophytes Gelidium corneum (formerly G. sesquipedale) and Pterocladiella capillacea (formerly Pterocladia capillacea) which are commercially harvested for the agar industry. Ardré $(1970,1971)$, studied the Portuguese algal flora of the mainland and Araújo et al. (2009), updated the benthic marine macroalgal checklist of the north coast of Portugal.

\footnotetext{
* Corresponding author. Tel.: +351 239855241; fax: +35123985511.

E-mail address: leonel@bot.uc.pt (L. Pereira).

URLs: http://macoi.ci.uc.pt/ (L. Pereira), http://www.nizo.com (F. van de Velde).
}

The centre/northern shores are dominated by seaweed species such as Himanthalia elongata, Gelidium corneum, Bifurcaria bifurcata, Chondrus crispus, Mastocarpus stellatus, Calliblepharis jubata, Gigartina pistillata, Chondracanthus acicularis, Osmundea pinnatifida, Gelidium pulchellum and Pterosiphonia complanata (Ardré, 1970; Pereira, Amado, Critchley, van de Velde, \& Ribeiro-Claro, 2009; Sousa-Pinto \& Araújo, 2006), many of these are carrageenophyte species.

Many seaweeds produce hydrocolloids, associated with the cell wall and intercellular spaces. Members of the red algae (Rhodophyta) produce galactans (e.g. carrageenans and agars) and the brown algae (Phaeophyceae) produce uronates (alginates). Carrageenans represent one of the major texturising ingredients used by the food industry. Carrageenans are natural ingredients, which have been used for decades in food applications and are generally regarded as safe (GRAS). Agar was the first colloid to be developed and it has applications as a gelling agent for food and also as an inert support medium for microbial culture. This polysaccharide is the dried hydrophilic, colloidal substance extracted commercially from certain red seaweeds.

The phycocolloid "carrageenan", as it was first called, was discovered by the British pharmacist Stanford in 1862 who extracted it from Irish Moss (Chondrus crispus). The name was later changed 


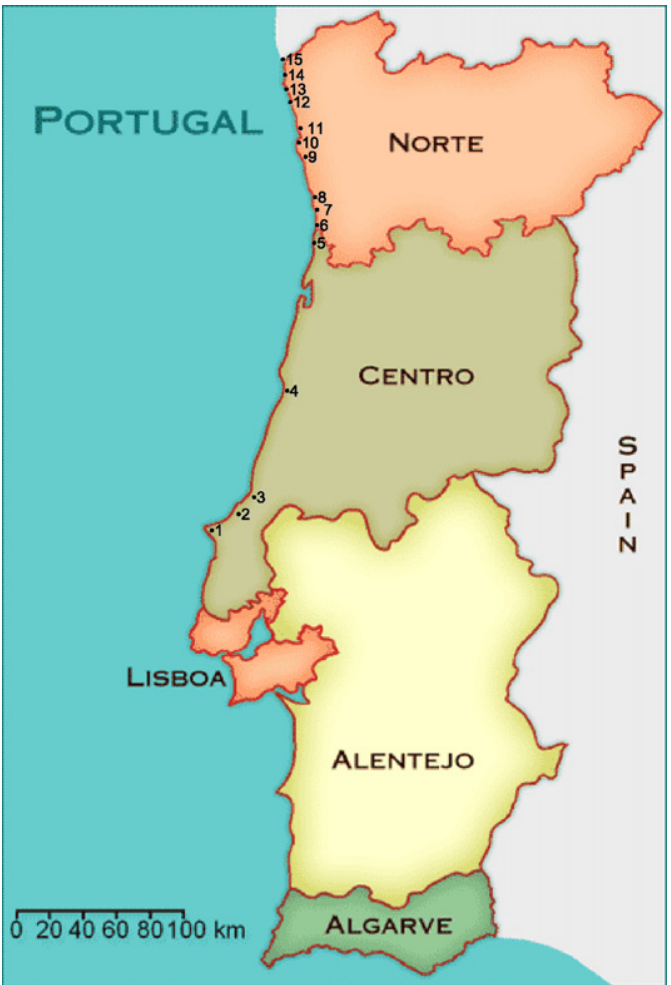

Fig. 1. Map of the sampling localities, marked with numbers (see Table 1).

to carrageenan so as to comply with the '-an' suffix for the names of polysaccharides. The modern carrageenan industry dates from the 1940s, receiving its impetus from the dairy industry where carrageenan was found to be the ideal stabilizer for the suspension of cocoa in chocolate milk. Next to dairy products, carrageenans are widely used in ice cream, paints, water gels, pharmaceuticals, and oil well drilling.

Commercial carrageenans are normally divided into three structural types: i.e. kappa, iota and lambda forms. The idealized disaccharide repeating units of these carrageenans are given in Figs. 1 and 2. Generally, seaweeds do not produce these idealized and pure carrageenans, but rather a range of hybrid structures. Several other carrageenan repeating units exist: e.g. xi, theta, beta, mu and nu (see Fig. 2). The precursors (mu and nu), when exposed to alkali conditions, are modified into kappa and iota, respectively, through formation of the 3,6-anhydro-galactose bridge (Rudolph, 2000).

Different types of carrageenan are obtained from different species of the Gigartinales (Rhodophyta). Kappa-carrageenan is predominantly obtained by extraction from the cultivated, tropical seaweed Kappaphycus alvarezii (known in the trade as "cottonii). Eucheuma denticulatum (trade name "spinosum") is the main species for the production of iota-carrageenan. Lambdacarrageenan is obtained from different species from the genera Gigartina and Chondrus (trade name "Irish Moss") (van de Velde \& de Ruiter, 2002). Other related lambda-type carrageenans include xi and theta-carrageenan (Pereira \& Mesquita, 2003). Small amounts of theta-carrageenan have been found in extracts of tetrasporic Gigartina and Chondracanthus species. Theta-carrageenan is also formed by alkaline treatment of lambda-carrageenan (Falshaw, Bixler, \& Johndro, 2003).

Kappa and iota hybrid carrageenans and their biochemical precursors are found in the gametophytic life phase of various species in the family Gigartinaceae (Rhodophyta). Co-polymers of kappa and iota carrageenan are referred to as "k-2" carrageenan, "kappa/iota-hybrids" or "weak-gelling" kappa by the seaweed processing industry and all produce gels under certain conditions (Falshaw et al., 2003; van de Velde, Peppelman, Rollema, \& Tromp, 2001; van de Velde et al., 2005). The rheological properties of the gelling carrageenans (e.g. kappa and iota) are quite distinct: the kappa-type forms gels that are hard, strong and brittle, whereas iota-carrageenan forms soft and weak gels. The common feature of these carrageenans is the anhydro-galactose bridge of the 4-linked galactose residue, respectively DA and DA2S, which adopts the ${ }^{1} C_{4^{-}}$ chair conformation. This conformation is crucial for the formation of the helical structure and, thereby, for the ability to form a gel. Lambda-carrageenan and the precursors mu- and nu-carrageenan lack the 3,6-anhydro bridge and, therefore, the 4-linked residue adopts the ${ }^{4} C_{1}$-chair conformation, which disturbs the helical conformation. Thus, lambda-carrageenan acts simply as a thickening agent.

The aim of the current study was twofold. Firstly, to analyze the composition of the polysaccharides produced by Portuguese carrageenophytes, through resonance spectroscopy techniques. ${ }^{1} \mathrm{H}$ NMR spectroscopy is used for the quantitative analysis of the different repeating units of the hybrid carrageenans, extracted from the studied algae. ${ }^{1} \mathrm{H}$ NMR allows for the identification and quantification of different carrageenan types based on the intensity and the chemical shift of the resonances of the anomeric protons (van de Velde, Knutsen, Usov, Rollema, \& Cerezo, 2002). The second objective of the study was to analyze the geographic distribution of Portuguese carrageenophytes and their phycocolloid ecology (life-cycle phases, dry weight and carrageenan content).

\section{Materials and methods}

\subsection{Algal material}

All seaweed studied belonging to the Gigartinales were widely distributed along the Portuguese coast. In this study eight different species, belonging to seven genera and three families, were studied: Chondrus crispus Stackhouse (Gigartinaceae); Gigartina pistillata (S.G. Gmelin) Stackhouse (Gigartinaceae); Chondracanthus teedei (Mertens ex Roth) Kützing and Gigartina teedei var. lusitanicus (J.E. De Mesquita Rodrigues) Bárbara \& Cremades (Gigartinaceae); Chondracanthus acicularis (Roth) Fredericq (Gigartinaceae); Mastocarpus stellatus (Stackhouse) Guiry (Phyllophoraceae); Ahnfeltiopsis devoniensis (Greville) P.C. Silva \& DeCew (Phyllophoraceae); Gymnogongrus crenulatus (Turner) J. Agardh (Phyllophoraceae); Calliblepharis jubata (Goodenough \& Woodward) Kützing (Cystocloniaceae).

In order to analyze the geographical distribution of the carrageenophytes and the variation of their carrageenan content, harvests were made during the summer of 2003, at 15 locations, from the south to the north of the portuguese coast (see Fig. 1 and Tables 1 and 2).

\subsection{Dry weight and carrageenan content}

For dry weight and carrageenan evalution, 100 individuals plants of more than $3 \mathrm{~cm}$ length, of each species, were collected randomly at each site. In the laboratory, carrageenophytes were sorted into their different life-cycle phases, using a stereomicroscope, and then rinsed in distilled water to eliminate debris and salt. The plants were dried, in a ventilated oven, to constant weight at $60^{\circ} \mathrm{C}$, according to the process described by Pereira, Sousa, Coelho, Amado, and Ribeiro-Claro (2003) and Pereira and Mesquita (2004). The results were presented as average \pm standard error (with $n=$ number of samples used in study). 
<smiles>COC1C(O)C(CO)OC(OCC2C3COC(O3)C(C)C2O)C1O</smiles>

G

Beta-carrageenan

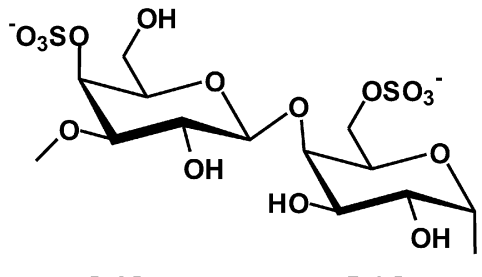

G4S Mu-carrageenan

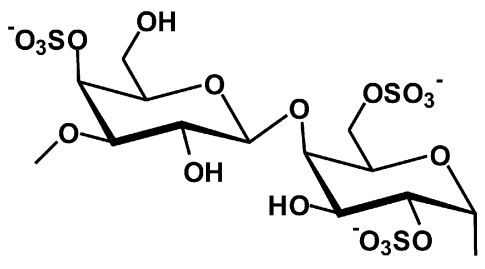

G4S Nu-carrageenan

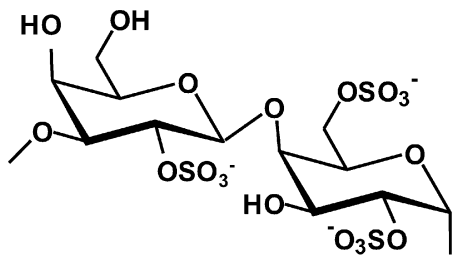

G2S

D2S,6S

Lambda-carrageenan

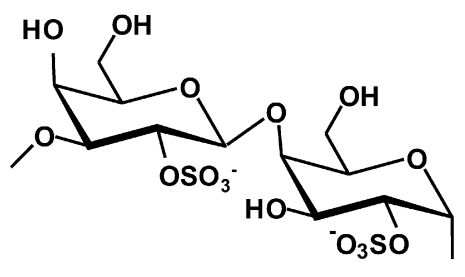

G2S D2S
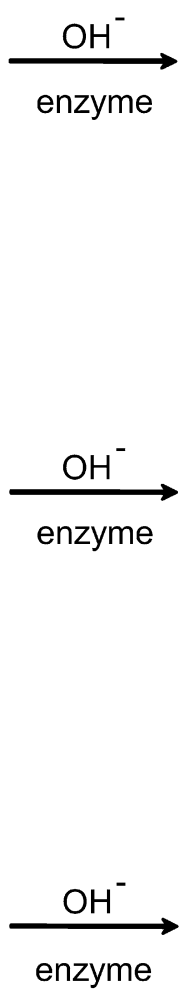

Theta-carrageenan
G2S
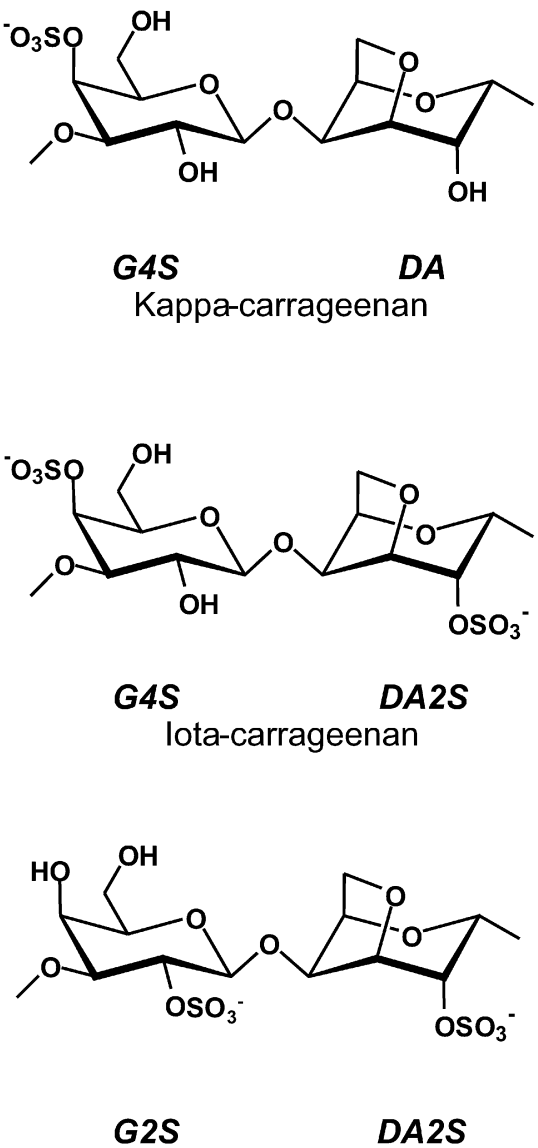

A2S

Xi-carrageenan

Fig. 2. Idealized units of the main carrageenan types.

Prior to phycocolloid extraction, the ground, dry material was rehydrated and pre-treated with $100 \%$ methanol and $100 \%$ acetone (1:1) to eliminate the organ-soluble fraction (Zinoun \& Cosson, 1996).

For extraction of the "native" phycocolloid, the samples were placed in distilled water $(50 \mathrm{~mL} / \mathrm{g}), \mathrm{pH} 7$ at $85^{\circ} \mathrm{C}$ for $3 \mathrm{~h}$. For an alkaline-extraction (closely resembling the industrial extraction), the samples were placed in a solution $(150 \mathrm{~mL} / \mathrm{g})$ of $\mathrm{NaOH}(1 \mathrm{M})$ at $80 / 85^{\circ} \mathrm{C}$ for $3 / 4 \mathrm{~h}$, and neutralized to $\mathrm{pH} 6 / 8$ with $\mathrm{HCl}(0.3 \mathrm{M})$, according to the method described by Pereira (2006) and Pereira, Critchley, Amado, and Ribeiro-Claro, (2009).

The solutions were hot filtered, twice, under vacuum, through cloth and fibreglass filter. The extract was evaporated under vacuum to one-third of the initial volume. The carrageenan was precipitated by adding the warm solution to twice its volume of $96 \%$ ethanol. Coagula were dried for $48 \mathrm{~h}$ at $60^{\circ} \mathrm{C}$, and then weighed to determine the carrageenan content (\% of dry weight) (Pereira \& Mesquita, 2004). Each sample was 
Table 1

Geographic distribution of the carrageenophytes.

\begin{tabular}{|c|c|c|c|c|c|c|c|c|c|}
\hline $\begin{array}{l}\text { Sampling } \\
\text { sites }\end{array}$ & $\begin{array}{l}\text { Carrageenophyte } \\
\rightarrow \text { Coordinates }\end{array}$ & $\begin{array}{l}\text { Chondrus } \\
\text { crispus }\end{array}$ & $\begin{array}{l}\text { Gigartina } \\
\text { pistillata }\end{array}$ & $\begin{array}{l}\text { Chondracanthus } \\
\text { teedei }\end{array}$ & $\begin{array}{l}\text { Chondrus } \\
\text { acicularis }\end{array}$ & $\begin{array}{l}\text { Mastocarpus } \\
\text { stellatus }\end{array}$ & $\begin{array}{l}\text { Ahnfeltiopsis } \\
\text { devoniensis }\end{array}$ & $\begin{array}{l}\text { Gymnogongrus } \\
\text { crenulatus }\end{array}$ & $\begin{array}{l}\text { Calliblepharis } \\
\text { jubata }\end{array}$ \\
\hline 1 - Baleal & $39^{\circ} 22^{\prime} 21.61^{\prime \prime} \mathrm{N} ; 9^{\circ} 20^{\prime} 27.18^{\prime \prime} \mathrm{W}$ & & & - & - & & - & - & - (1) \\
\hline 2 - S. M. Porto & $39^{\circ} 31^{\prime} 15.00^{\prime \prime} \mathrm{N} ; 9^{\circ} 8^{\prime} 27.37^{\prime \prime} \mathrm{W}$ & (1) & $\bullet$ & & & $\bullet$ & & $\bullet$ & (1) \\
\hline 3 - S. P. Moel & $39^{\circ} 45^{\prime} 44.63^{\prime \prime} \mathrm{N} ; 9^{\circ} 1^{\prime} 58.13^{\prime \prime} \mathrm{W}$ & $\bullet$ & $\bullet$ & & & & $\bullet$ & - & \\
\hline $4-$ Buarcos & $40^{\circ} 10^{\prime} 6.99^{\prime \prime} \mathrm{N} ; 8^{\circ} 53^{\prime} 19.56^{\prime \prime} \mathrm{W}$ & - & - & $\bullet(2)$ & - & - & - & - & $\bullet$ \\
\hline 5 - Aguda & $41^{\circ} 2^{\prime} 37.03^{\prime \prime} \mathrm{N} ; 8^{\circ} 39^{\prime} 6.70^{\prime \prime} \mathrm{W}$ & $\bullet$ & $\bullet$ & - (2) & - (1) & - & - (1) & - & $\bullet$ \\
\hline 6 - Miramar & $41^{\circ} 4^{\prime} 6.66^{\prime \prime} \mathrm{N} ; 8^{\circ} 39^{\prime} 30.39^{\prime \prime} \mathrm{W}$ & $\bullet$ & & - $(1,2)$ & & $\bullet$ & $\bullet$ & $\bullet$ & $\bullet$ \\
\hline 7 - Lavadores & $41^{\circ} 7^{\prime} 18.35^{\prime \prime} \mathrm{N} ; 8^{\circ} 40^{\prime} 5.11^{\prime \prime} \mathrm{W}$ & - & & - (2) & & - & & - (1) & \\
\hline 8 - Valadares & $41^{\circ} 7^{\prime} 48.83^{\prime \prime} \mathrm{N} ; 8^{\circ} 40^{\prime} 10.24^{\prime \prime} \mathrm{W}$ & $\bullet$ & $\bullet$ & (2) & & $\bullet$ & $\bullet$ & $\bullet$ & $\bullet$ \\
\hline 9 - A-Ver-o-Mar & $41^{\circ} 24^{\prime} 16.73^{\prime \prime} \mathrm{N} ; 8^{\circ} 46^{\prime} 50.59^{\prime \prime} \mathrm{W}$ & $\bullet$ & - & - (2) & & $\bullet$ & & $\bullet$ & - \\
\hline 10 - Aguçadoura & $41^{\circ} 25^{\prime} 58.82^{\prime \prime} \mathrm{N} ; 8^{\circ} 47^{\prime} 5.34^{\prime \prime} \mathrm{W}$ & $\bullet$ & $\bullet$ & $\bullet(2)$ & $\bullet$ & $\bullet$ & & $\bullet$ & $\bullet$ \\
\hline 11 - Apúlia & $41^{\circ} 29^{\prime} 12.42^{\prime \prime} \mathrm{N} ; 8^{\circ} 46^{\prime} 55.46^{\prime \prime} \mathrm{W}$ & $\bullet$ & - & (2) & & $\bullet$ & & - & $\bullet$ \\
\hline 12 - Praia Norte & $41^{\circ} 41^{\prime} 48.38^{\prime \prime} \mathrm{N} ; 8^{\circ} 51^{\prime} 6.24^{\prime \prime} \mathrm{W}$ & - & - & - (2) & - & - & & - & - \\
\hline 13 - Afife & $41^{\circ} 46^{\prime} 56.99^{\prime \prime} \mathrm{N} ; 8^{\circ} 52^{\prime} 20.63^{\prime \prime} \mathrm{W}$ & - & - & & & - & - & - & \\
\hline 14 - Vila P. Âncora & $41^{\circ} 49^{\prime} 38.71^{\prime \prime} \mathrm{N} ; 8^{\circ} 52^{\prime} 26.61^{\prime \prime} \mathrm{W}$ & - & $\bullet$ & $\bullet(2)$ & - & - & & - & $\bullet(1)$ \\
\hline 15 - Moledo & $41^{\circ} 50^{\prime} 40.32^{\prime \prime} \mathrm{N} ; 8^{\circ} 52^{\prime} 15.25^{\prime \prime} \mathrm{W}$ & $\bullet$ & & - (2) & & - & - & - & \\
\hline
\end{tabular}

(1) Present, but insufficient for sampling; (2) C. teedei var. lusitanicus.

extracted in quadruplicate for carrageenan yield determinations.

\subsection{NMR analysis}

${ }^{1} \mathrm{H}$ NMR spectra were taken on a Bruker DRX500 spectrometer operating at $500.13 \mathrm{MHz}$ at $65^{\circ} \mathrm{C}$. Typically 64 scans were taken with an inter-pulse delay of $5 \mathrm{~s}$ ( $T_{1}$ values for the reso- nance of the anomeric protons of kappa- and iota-carrageenan are shorter than $1.5 \mathrm{~s}$ ). Sample preparation for the ${ }^{1} \mathrm{H}$ NMR experiments involved dissolving the carrageenan sample $(5 \mathrm{mg} / \mathrm{mL})$ at $80^{\circ} \mathrm{C}$ in $\mathrm{D}_{2} \mathrm{O}$ containing $1 \mathrm{mM}$ TSP (3-(trimethylsilyl) propionic-2,2,3,3- $d_{4}$ acid sodium salt) and $20 \mathrm{mM} \mathrm{Na}_{2} \mathrm{HPO}_{4}$, followed by three sonication, one hour periods (Branson 2510). Aliquots of the sonicated solutions were transferred to NMR tubes and analyzed, according to Pereira, van de Velde and Mesquita (2007). Chemical shifts $(\delta)$

Table 2

Carrageenan composition determined by ${ }^{1} \mathrm{H}$ NMR spectroscopy.

\begin{tabular}{|c|c|c|c|c|c|c|c|c|c|}
\hline \multirow[b]{3}{*}{ Carrageenophyte and extraction method } & \multicolumn{8}{|c|}{ Composition of carrageenan repeating units ${ }^{a}$} & \multirow[b]{2}{*}{ Starch } \\
\hline & Kappa & Iota & $\mathrm{Mu}$ & $\mathrm{Nu}$ & Lambda & Theta & $\mathrm{Xi}$ & Pyruvate & \\
\hline & $(\mathrm{mol} \%)$ & $(\mathrm{mol} \%)$ & (mol\%) & $(\mathrm{mol} \%)$ & $(\mathrm{mol} \%)$ & $(\mathrm{mol} \%)$ & $(\mathrm{mol} \%)$ & $(\mathrm{mol} \%)^{\mathrm{b}}$ & $(\%)^{\mathrm{c}}$ \\
\hline \multicolumn{10}{|l|}{ Ahnfeltiopsis devoniensis $\mathrm{G}$} \\
\hline Alkaline & $17-35$ & $65-83$ & - & - & - & - & - & - & - \\
\hline \multicolumn{10}{|l|}{ Caliblepharis jubata FG } \\
\hline $\begin{array}{l}\text { Alkaline } \\
\text { Caliblepharis jubata NF}\end{array}$ & - & 80 & - & 20 & - & - & - & - & - \\
\hline $\begin{array}{l}\text { Alkaline } \\
\text { Caliblepharis jubata T }\end{array}$ & $0-2$ & 89-100 & - & $0-9$ & - & - & - & - & $23-25$ \\
\hline \multicolumn{10}{|l|}{ Chondracanthus acicularis FG } \\
\hline Water & 59 & 34 & - & - & - & - & - & 7 & - \\
\hline Alkaline & 60 & 35 & - & - & - & - & - & 5 & 7 \\
\hline \multicolumn{10}{|l|}{ Chondracanthus acicularis $\mathrm{T}$} \\
\hline $\begin{array}{l}\text { Alkaline } \\
\text { Chondracanthus teedei FG }\end{array}$ & 23 & - & - & - & - & 31 & 45 & - & - \\
\hline Water & 53 & 37 & 5 & 5 & - & - & - & - & - \\
\hline Alkaline & 58 & 42 & - & - & - & - & - & - & 5 \\
\hline \multicolumn{10}{|l|}{ Chondracanthus teedei NF } \\
\hline Water & $47-51$ & $39-46$ & $0-2$ & $7-9$ & - & - & - & - & $0-3$ \\
\hline Alkaline & $49-51$ & $49-51$ & - & - & - & - & - & - & - \\
\hline \multicolumn{10}{|l|}{ Chondracanthus teedei $\mathrm{T}$} \\
\hline Water & - & - & - & - & - & 33 & 67 & - & - \\
\hline Alkaline & - & - & - & - & - & 33 & 67 & - & - \\
\hline \multicolumn{10}{|l|}{ Chondrus crispus FG } \\
\hline Alkaline & 70 & 28 & - & - & - & - & _ & _ & $2-6$ \\
\hline \multicolumn{10}{|l|}{ Chondus crispus $\mathrm{T}$} \\
\hline Alkaline & - & - & - & - & $96-100$ & - & - & - & $0-4$ \\
\hline \multicolumn{10}{|l|}{ Gigartina pistillata FG } \\
\hline Alkaline & $35-49$ & $45-54$ & - & - & - & - & - & $6-11$ & - \\
\hline \multicolumn{10}{|l|}{ Gymnogongrus crenulatus ТВ } \\
\hline Alkaline & $60-64$ & $29-32$ & $2-4$ & - & - & - & - & $5-7$ & $5-13$ \\
\hline \multicolumn{10}{|l|}{ Mastocarpus stellatus G } \\
\hline Alkaline & 62 & 36 & - & - & - & - & - & 2 & 7 \\
\hline
\end{tabular}

T - tetrasporophytes; FG - female gametophytes; G - gametophytes; NF - non-fructified thalli; TB - tetrasporoblastic thalli. (a) Molar fraction of the carrageenan repeating units: defined as the integrated intensity of the corresponding anomeric proton/sum of the integrated intensities of all assigned carrageenan anomeric protons (including pyruvated carrageenan). Ranges indicate that for a specific species several samples were analyzed with ${ }^{1} \mathrm{H}$ NMR spectroscopy. (b) Integrated intensity of the pyruvated carrageenan signal at $5.49 \mathrm{ppm} / \mathrm{sum}$ of the integrated intensities of all assigned carrageenan anomeric protons. (c) Integrated intensity of the signal at 5.35 ppm/total integrated intensity between 5.0 and $5.7 \mathrm{ppm}$. 


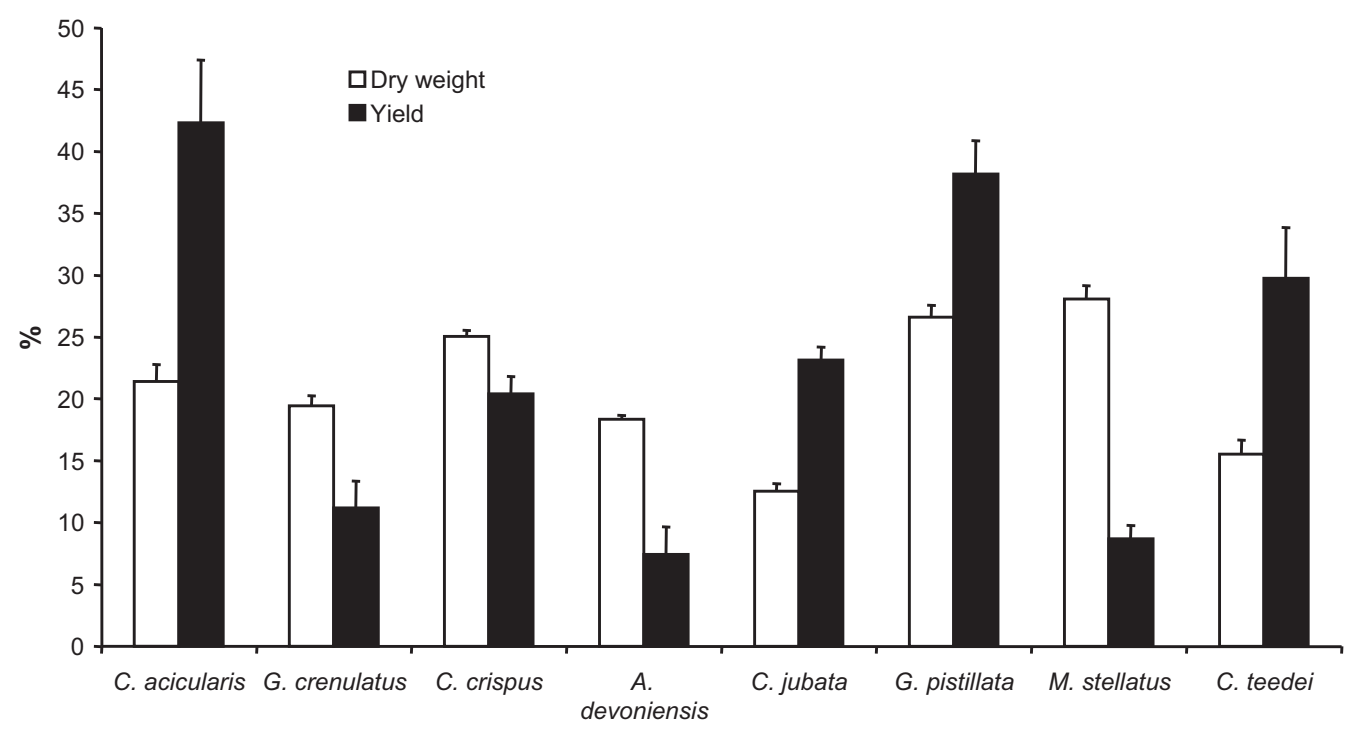

Fig. 3. Dry weight (\% fresh weight) and carrageenan content (\% dry weight). Average standard error $(n=15)$.

were referred to internal TSP standard ( $\delta=0.017 \mathrm{ppm}$ ) relative to the IUPAC recommended standard DSS for ${ }^{1} \mathrm{H}$. Assignment of the ${ }^{1} \mathrm{H}$ NMR spectra as based on the chemical shift data summarized by van de Velde and de Ruiter (2002) and van de Velde, Pereira, and Rollema (2004).

\subsection{Size-exclusion chromatography-multiangle laser light scattering (SEC-MALLS) analysis}

Size-exclusion chromatography was performed at a constant flow rate of $1 \mathrm{mLmin}^{-1}$ using TSK-gel 6000PW and TSK-gel 3000PW columns (Phenomenex) in series with a TSK guard column (Phenomenex). Detection was done simultaneously with a RI (refractive index) detector (ERC 7510 RI; Erma Optical Works Ltd.), an optical rotation detector (OR-1590 chiral detector; Jasco), and a multi-angle laser light scattering detector (Dawn DSP-F; Wyatt Technology Corp.). Data analysis was performed using ASTRA for Windows software (Wyatt Technology Corp.). The columns were controlled thermostatically in a column oven (Waters chromatography). A programmable HPLC pump (LC-10AT; Shimadzu) with an in-line degassing unit (X-Act; Jour Research) was used. An auto-sampler (Dilutor 401; Gilson) coupled to a waterbath (F3; Haake) was used for injection of the samples. Analysis of the carrageenans in the coil conformation was performed with a $0.1 \mathrm{M}$ $\mathrm{LiNO}_{3}$ solution as eluent and a system temperature of $45^{\circ} \mathrm{C}$. Samples were prepared by adding MilliQ water $(5 \mathrm{~mL})$ to carrageenan $(10 \mathrm{mg})$. After storage overnight at $4{ }^{\circ} \mathrm{C}$, the samples were heated to $80^{\circ} \mathrm{C}$ for $30 \mathrm{~min}$. Before analysis the samples were diluted with a concentrated $\mathrm{LiNO}_{3}$ solution to the concentration of the eluent.

\subsection{Inductively coupled plasma-atomic emission spectrometry (ICP-AES) analysis}

The cation composition of the crude and purified samples was determined by inductively coupled plasma-atomic emission spectrometry (ICP-AES analysis). Carrageenan ( $25 \mathrm{mg}$ ) was incinerated and subsequently dissolved in sulfuric acid ( $1 \mathrm{~mL} ; 65 \% \mathrm{wt} / \mathrm{wt})$. After dilution with double-distilled water $(9 \mathrm{~mL})$, the samples were analyzed using a Vista CCD simultaneous axial ICP-AES from Varian. Calibration was done with a multi-element solution containing $\mathrm{Ca}$, $\mathrm{K}, \mathrm{Mg}$ and $\mathrm{Na}$.

\section{Results and discussion}

\subsection{Carrageenophytes distribution and lifecycle phase}

The carrageenophytes species selected occur commonly at the central and northern coast of Portugal and some are even the dominant species of the algal flora in middle littoral zone. The geographical distribution is given in Table 1 and shown in Fig. 1. Regarding the distribution, C. crispus and M. stellatus were found to be widely distributed, being present at 13 of a total of 15 sites analyzed. C. teedei (12 sites) and G. pistillata (11 sites) also had a wide distribution. G. crenulatus, despite having a low coverage (Pereira, 2004), was the only carrageenophyte found to occur at all of the sites.

C. acicularis, was found to have a large coverage and is considered a common species in the Portuguese algal flora, forming dense turfs (Ardré, 1970; Sousa-Pinto, 1998); however, was only present in 6 collecting sites. One possible explanation for this observation may be related to the reduced coverage of the alga over summer (Pereira, 2004).

The average dry weight and carrageenan content of species collected from the different harvesting locations are shown in Fig. 3. The average dry weight, expressed as percentage of fresh weight, was the lowest (12.5\%) in samples of C.jubata and greatest (28.1\%) in samples of $M$. stellatus. The average carrageenan content, expressed as percentage of dry weight, was lowest (7.4\%) in samples of $A$. devoniensis and greatest (42.3\%) in samples of C. acicularis. The population structure at the different sampling sites is given in the Figs. 4-8 for C. crispus, G. pistillata, C. teedei, M. stellatus and C. Jubata respectively.

In general, female gametophytes were found to be present at coastal stations of warmer waters (situated in south sites); the tetrasporic thalli were present mainly at the coastal sites with cooler water, e.g. located in the north (see Table 1, Figs. 1, 4, 5, 6, 7 and 8). An example of this pattern can be found by examining the results concerning the structure of populations of C. crispus from the different coastal sites (Fig. 4). Thus, cystocarpic thalli were present (and predominantly in some sites) especially at the coastal sites located at south direction, e.g. Miramar, Buarcos, and S.M. Porto, while the tetrasporic thalli were present in samples collected at sites further north, e.g. Lavadores, Valadares, A-Ver-o-Mar, Apúlia, Aguçadoura, Praia Norte, Afife, V.P. Âncora and Moledo. A similar situation was found in populations of $G$. pis- 


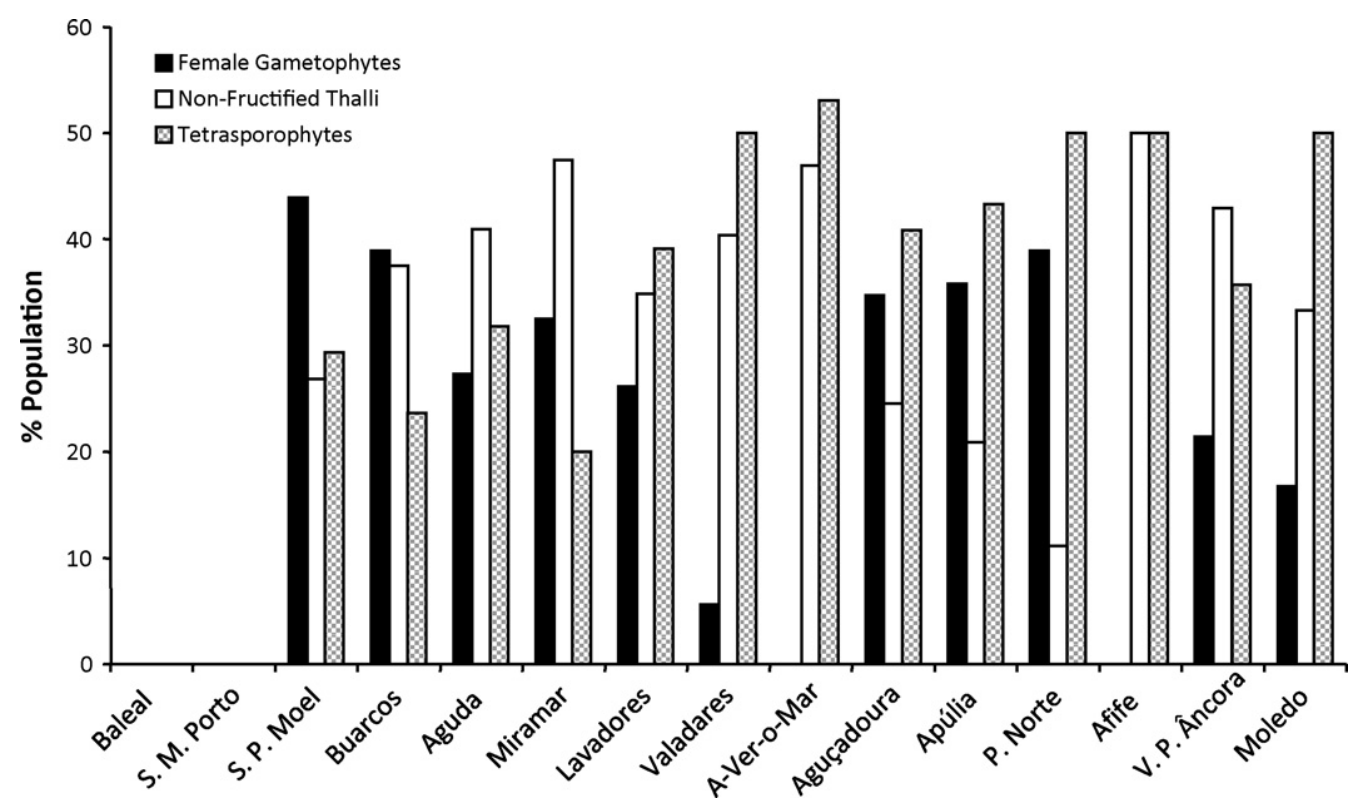

Fig. 4. Population structure of $C$. crispus in different sampling sites.

tillata (Fig. 5) and C. teedei var. lusitanicus (Fig. 6), where there was a predominance of non-fructified thalli at cold water sites, e.g. from Lavadores to Moledo; female gametophytes were present at the warmer waters sites, especially at locations south of Buarcos. In some sites (e.g. Buarcos, A-Ver-o-Mar and Praia Norte) plants of G. pistillata exhibiting both tetrasporangial sori and cystocarps, i.e. tetraspores and carpospores (heterosporic thalli), were found (see Fig. 5) (Pereira, 2004).

C. crispus and M. stellatus were the carrageenophytes with highest cover and biomass (see Fig. 3), with a wide geographic distribution, being present at 13 of the 15 sites analyzed (Table 1). G. crenulatus was the only study carrageenophyte of those studied that was present at all sites (Table 3). However the alga had low coverage, biomass and carrageenan content (see Fig. 3). From all of the carrageenophytes studied, the A. devoniensis had the lowest carrageenan content, lowest cover and biomass (Fig. 3).
C. teedei is an alga with isomorphic, tri-phasic life-cycle (Guiry, West, Kim \& Masuda, 1984; Pereira and Mesquita, 2004). Its tetrasporic thalli were present in all of the sites sampled (see Fig. 6). Samples of $C$. teedei were dominant from Aguda, Lavadores, Valadares, A-Ver-o-Mar, Aguçadoura, Apúlia, Praia Norte and V.P. de Âncora and ranged from $8.9 \%$ (Buarcos) to $100.0 \%$ (V.P. de Âncora). Female gametophytes were present in all samples except in V.P. de Âncora, with a minimum of 7.5\% (Praia Norte) and a maximum of $43.6 \%$ (Buarcos). Non-fructified thalli were present, as the female gametophytes, in all samples except in V.P. de Âncora, with a maximum of $47.5 \%$ at Buarcos and a minimum of $9.8 \%$ at Lavadores. The weight of plants ranged from $10.5 \pm 0.8 \%(n=3)$ in Lavadores and $22.0 \pm 0.9 \%(n=3)$ in Apúlia. The maximum carrageenan content was found in tetrasporic thalli from Aguda, at 68.0\%; the nonfructified fronds from Valadares and female gametophytes from Lavadores had the lowest at $10.0 \%$.

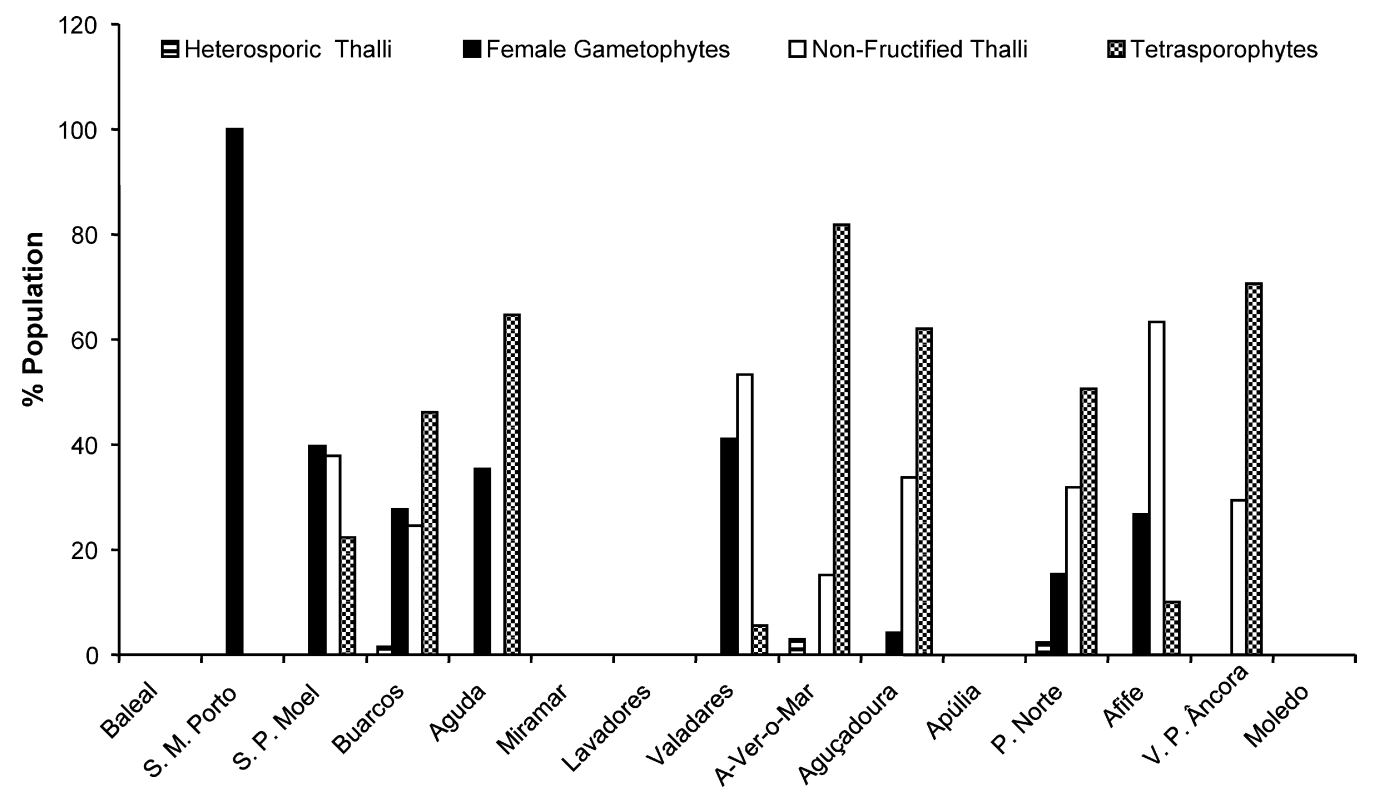

Fig. 5. Population structure of G. pistillata in different sampling sites. 


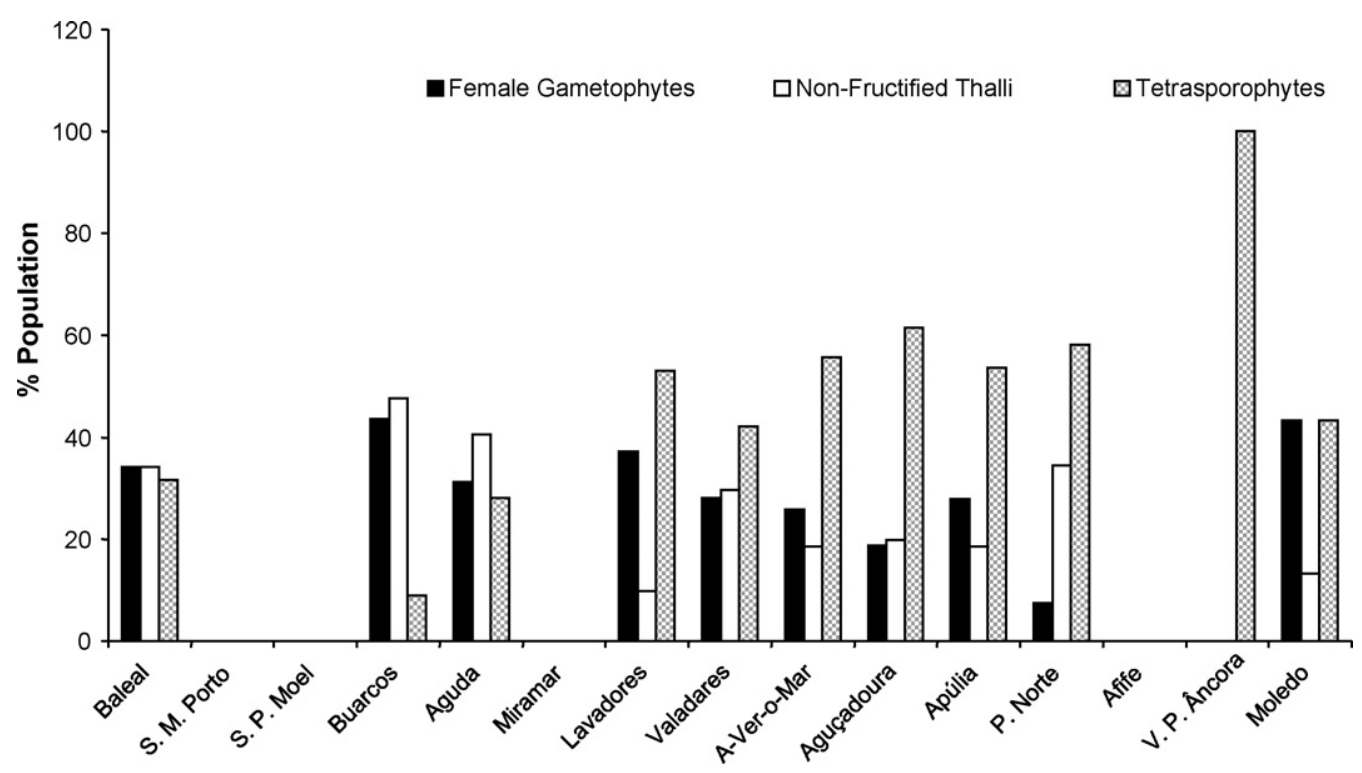

Fig. 6. Population structure of $C$. teedei in different sampling sites.

In conclusion, the combination of greater coverage, biomass and colloid content of $C$. teedei makes it a potential commercial source of the kappa/iota-carrageenan co-polymer, in addition to the traditionally carrageenophytes harvested in northern Portugal (C. crispus and M. stellatus) (Sousa-Pinto \& Araújo, 2006). Of the other algae studied, G. pistillata and C. acicularis, also had high carrageenan content, and could be considered as sources of co-polymers, both kappa/iota and lambda/theta/xi-carrageenans (Pereira, Critchley, et al., 2009).

\subsection{Carrageenan composition}

A summary of the carrageenan composition (determined by ${ }^{1} \mathrm{H}$ NMR spectroscopy) obtained from different Portuguese carrageenophyte studied is presented in Table $2 .{ }^{1} \mathrm{H}$ NMR spectra (region of the anomeric protons) of selected carrageenans, representing the major carrageenan repeating units, are given in Fig. 9. Signals at 5.29 and $5.09 \mathrm{ppm}$ corresponded to the anomeric proton of iota-carrageenan (DA2S) and kappa-carrageenan (DA), respectively. The presence of the nu (D2S, 6S) and mucarrageenan (D6S) precursors was identified by the signals at 5.50 and $5.24 \mathrm{ppm}$, respectively. The anomeric protons from the lambda-carrageenan family appeared at 5.55, 5.49 and $5.30 \mathrm{ppm}$, for lambda (D2S, 6S), xi (D2S) and theta-carrageenan (DA2S) respectively. Finally, pyruvate modifications were recognised as $5.49 \mathrm{ppm}$ and the presence of floridean starch was indicated at $5.35 \mathrm{ppm}$.

${ }^{1} \mathrm{H}$ NMR spectra of alkali extracted carrageenans from the gametophytes of $A$. devoniensis, in the region of anomeric protons, showed two main signals at 5.29 and $5.09 \mathrm{ppm}$. These signals corresponded to the anomeric proton of iota (DA2S) and kappacarrageenan (DA), respectively. A minor component detected in the spectrum revelled in a weak signal at $5.50 \mathrm{ppm}$ which corresponded to the presence of nu-carrageenan (D2S, 6S). The intensities of the resonances above were used to quantify each component in the carrageenan extracted from $A$. devoniensis (Table 2 ).

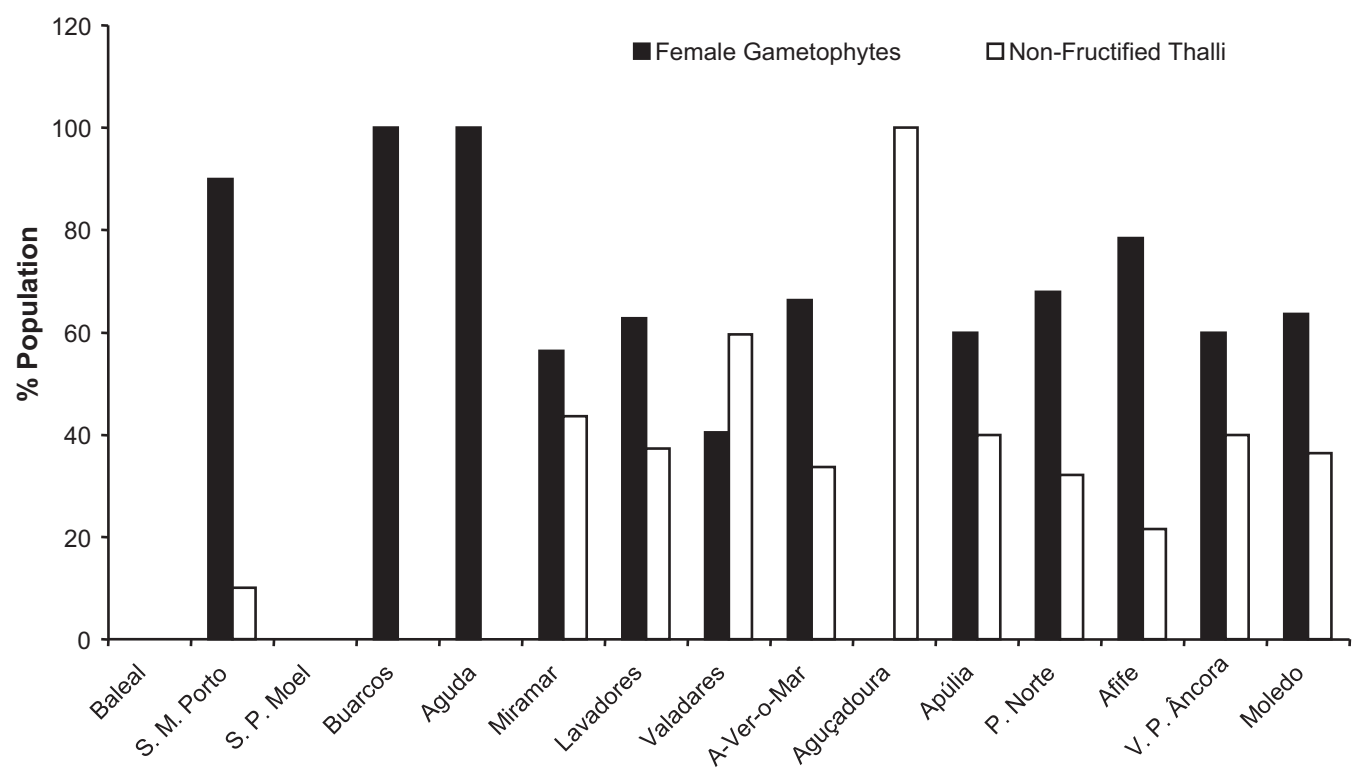

Fig. 7. Population structure of M. stellatus in different sampling sites. 


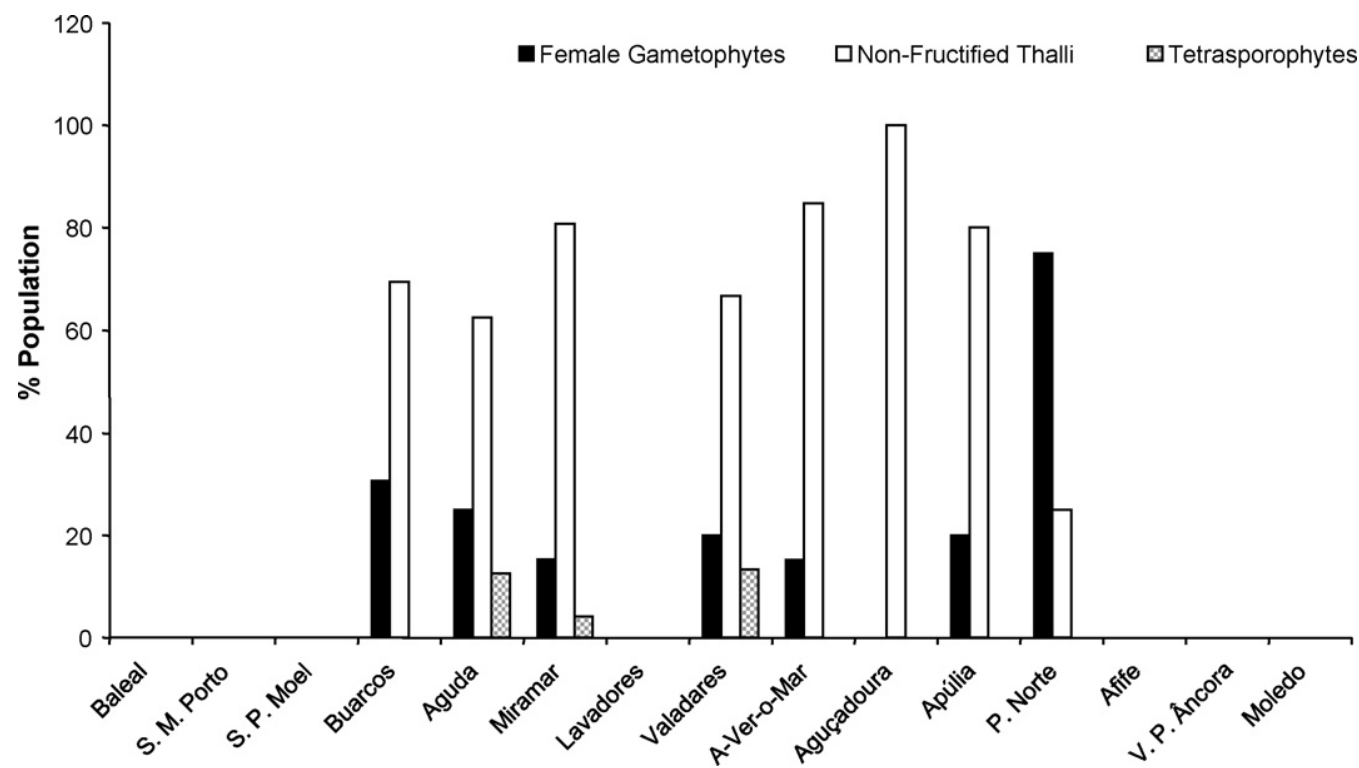

Fig. 8. Population structure of $C$. jubata in different sampling sites.

All spectra of $C$. jubata carrageenan showed three main signals: $5.50 \mathrm{ppm}$ (nu-carrageenan), $5.29 \mathrm{ppm}$ (iota-carrageenan) and 5.09 ppm (kappa-carrageenan) (Table 2).

The spectrum of $C$. acicularis (female gametophytes) alkaliextracted carrageenan presented two prominent signals at $5.29 \mathrm{ppm}$ (iota-carrageenan) and $5.09 \mathrm{ppm}$ (kappa-carrageenan), and two weaker signals to $5.49 \mathrm{ppm}$ (pyruvate) and $5.35 \mathrm{ppm}$ (floridean starch). The water-extracted carrageenan spectrum (from female gametophytes) showed the same signals, only missing the $5.35 \mathrm{ppm}$ peak referring to floridean starch. The spectrum of C. acicularis (tetrasporophytes) displayed signals at $5.49 \mathrm{ppm}(\mathrm{xi})$, $5.30 \mathrm{ppm}$ (theta) and $5.09 \mathrm{ppm}$ (kappa).

C. teedei var. lusitanicus (non-fructified and female gametophyte thalli) carrageenan spectra showed two prominent signals: i.e. $5.29 \mathrm{ppm}$ and $5.09 \mathrm{ppm}$. These signals corresponded to the anomeric proton of iota (DA2S) and kappa-carrageenan (DA), respectively. The minor component detected in the spectra, showed a slight rise at $5.35 \mathrm{ppm}$, corresponded to anomeric protons of floridean starch, a natural contaminant of some samples of carrageenan. Other minor components found in the native carrageenan spectra produced signals at $5.50 \mathrm{ppm}$ (i.e. mu-carrageenan) and $5.24 \mathrm{ppm}$ (i.e. nu-carrageenan), and corresponded to biological precursors of iota- and kappa-carrageenan, respectively. ${ }^{1} \mathrm{H}$ NMR spectra showed signals at $5.49 \mathrm{ppm}$ (i.e. xi-carrageenan) and $5.30 \mathrm{ppm}$ (i.e. theta-carrageenan) in all tetrasporophyte samples of $C$. teedei var. lusitanicus.

${ }^{1} \mathrm{H}$ NMR spectra of alkali-extracted carrageenans of M. stellatus (gametophytes) and G. crenulatus (tetrasporoblastic thalli) showed two main signals: i.e. 5.09 ppm (kappa-carrageenan) and $5.29 \mathrm{ppm}$ (iota-carrageenan); two additional signals were present at $5.35 \mathrm{ppm}$ (i.e. floridean starch) and $5.49 \mathrm{ppm}$ (i.e. pyruvate).

${ }^{1} \mathrm{H}$ NMR spectra of alkali-extracted carrageenans from $C$. crispus and G. pistillata (female gametophytes and tetrasporophytes) showed five distinct signals: $5.09 \mathrm{ppm}$ (kappa); $5.29 \mathrm{ppm}$ (iota); $5.55 \mathrm{ppm}$ (lambda); 5.49 (xi); $5.30 \mathrm{ppm}$ (pyruvate) and 5.35 (floridean starch).

The molecular weights of alkali- and water-extracted carrageenans are shown in Table 3 . In general, we can conclude that the hybrid carrageenans extracted from $C$. crispus (i.e. the seaweed commonly used by industry) and $C$. teedei var. lusitanicus have

Table 3

Molecular weight and cationic composition of the extracted carrageenans.

\begin{tabular}{|c|c|c|c|c|c|c|}
\hline \multirow[t]{2}{*}{ Carrageenophyte and extraction method } & \multicolumn{2}{|c|}{ Molecular weight (kDa) } & \multicolumn{4}{|c|}{ Cationic composition ( $\mathrm{mol} \%$ ) } \\
\hline & Solid extract & Liquid extract & $\mathrm{Na}$ & K & $\mathrm{Ca}$ & $\mathrm{Mg}$ \\
\hline Ahnfeltiopsis devoniensis $\mathrm{G}$ alkaline & 1020 & 656 & 90 & 6 & 4 & 0 \\
\hline Chondracanthus acicularis FG water & 396 & & & & & \\
\hline Alkaline & 403 & & & & & \\
\hline C. acicularis $\mathrm{T}$ water & 725 & & & & & \\
\hline Chondrus crispus NF water & 440 & & & & & \\
\hline Alkaline & 827 & 628 & 98 & & & \\
\hline C. crispus FG water & & 536 & & & & \\
\hline Alkaline & & 559 & & & & \\
\hline C. crispus $\mathrm{T}$ water & & 1641 & & & & \\
\hline Chondracanthus teedei var. lusitanicus FG water (by autoclaving) & 43 & & & & & \\
\hline Water & & 678 & 47 & 27 & 7 & 19 \\
\hline C. teedei var. lusitanicus NF water & 542 & 636 & 83 & 11 & 2 & 5 \\
\hline Alkaline & 1148 & 719 & 82 & 2 & 8 & 7 \\
\hline C. teedei var. lusitanicus $\mathrm{T}$ water & & & 49 & 27 & 6 & 17 \\
\hline Alkaline & & 951 & & & & \\
\hline Gigartina pistillata $\mathrm{T}$ water & 519 & & & & & \\
\hline Gymnogongrus crenulatus TB alkaline & & & 88 & 10 & 2 & 1 \\
\hline Mastocarpus stellatus G water & 491 & & & & & \\
\hline
\end{tabular}

T - tetrasporophytes; FG - female gametophytes; G - gametophytes; NF - non-fructified thalli; TB - tetrasporoblastic thalli. 


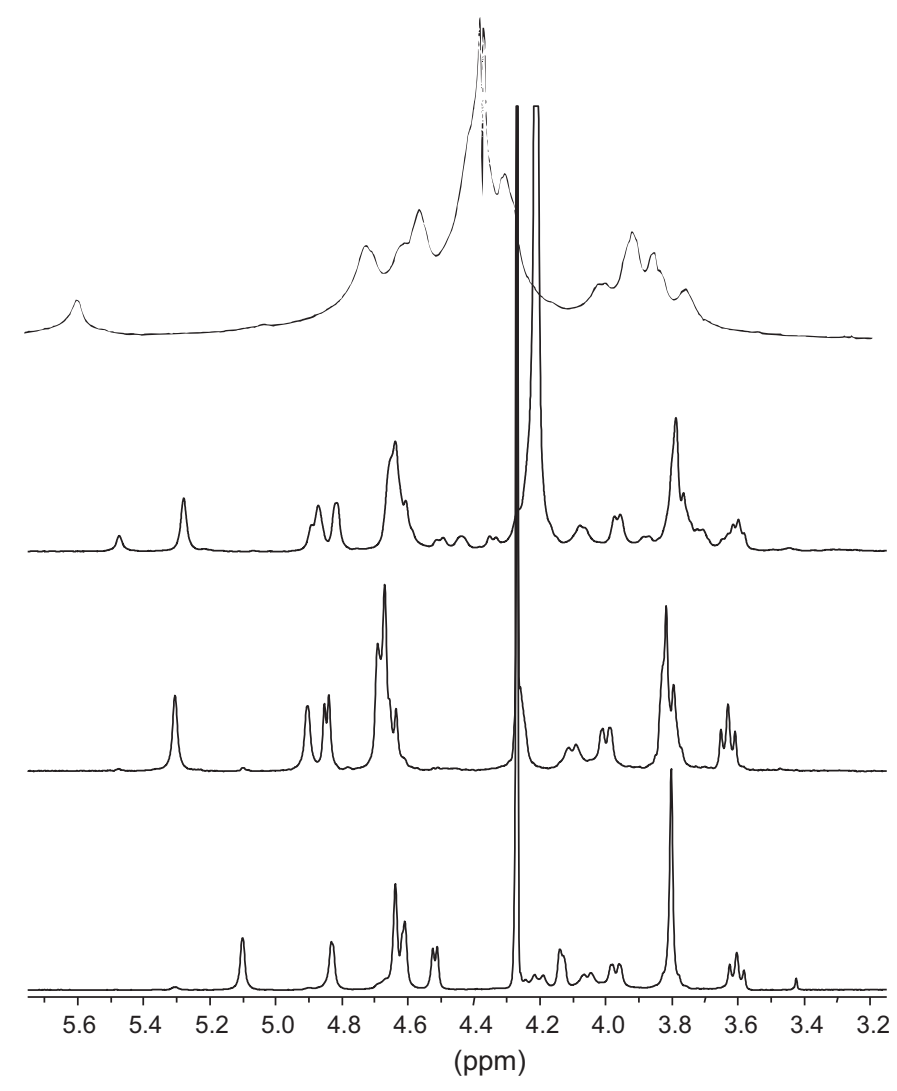

Fig. 9. ${ }^{1} \mathrm{H}$ NMR spectra of the major carrageenan types (with permission of Elsevier adopted from van de Velde, Knutsen, Usov, Rollema and Cerezo, 2002) from bottom to top: kappa-carrageenan from Kappaphycus alvarezii; iota-carrageenan from Eucheuma denticulatum; nu/iota-hybrid carrageenan containing 25\% nucarrageenan; lambda-carrageenan from Iridaea undulosa.

identical molecular weights (see Table 3). For the same species, the lambda family carrageenans (lambda and hybrid xi/theta) had molecular weights higher than those of the kappa family (hybrid kappa/iota) (see Table 3); samples from the aqueous extract showed, in general, a molecular weight lower than the alkaliextracted samples.

Native carrageenans are, in most cases, combinations of idealized carrageenan units (see Fig. 2 and Table 2), with variations in structure, not only between species but also between lifecycle phases. The structural difference of carrageenans also affects the phycocolloid physic-chemical properties and consequently, their industrial applications.

The biological precursors ( $\mathrm{mu}$ and $\mathrm{nu}$ ) of the gelling carrageenans (kappa and iota) contain a sulphate ester group at position 6 of $\alpha$-D-galactose 4 -connected (see Fig. 2). This type of structure reduces the ability of carrageenan to form a gel, due to the interruption of sequences of the repeating units responsible for the formation of the double helix structure typical of gel phase. Most of the 6-sulphated units are converted into the corresponding 3,6-anhydrous form, during a long, highly alkaline (usually $0.1 \mathrm{M}$ $\mathrm{Ca}(\mathrm{OH})_{2}$ ) extraction process. At the industrial level, the extraction processes are intended to enhance profitability and increase the gelling power of the carrageenans obtained. Alternatively, a lower percentage of 6-sulphated precursor units are converted into the corresponding 3,6-anhydrous form in shorter duration processes (i.e. 2-4h) and with a gentle alkaline (0.02-0.1 M NaOH). This was the method used in this study. In this type of extraction it is still possible to extract carrageenans with their biological precursors (see Table 2). The process of moderate alkaline extraction is used, at the industrial level, when cold soluble carrageenans and/or with the ability to increase the viscosity are required (Falshaw et al., 2003). The method of alkaline extraction used in this study (Pereira et al., 2003; Pereira \& Mesquita, 2004) allowed for extraction of carrageenan types with a low degree of degradation (Ciancia, Noseda, Matulewicz \& Cerezo, 1993) and thus with higher molecular weights. It has been confirmed that the carrageenan extraction of kappa family carrageenans, even under "soft" (low pressures and temperatures), promotes the cyclization of carrageenan precursors.

Besides temperature and duration of extraction, there are other factors affecting the molecular weight of extracted carrageenan. In general, it can be concluded that the samples of native carrageenan from the water-extraction method, exhibited a lower molecular weight than those resulting from alkali-extraction from the same material. The results of the study also indicated that the molecular weights of carrageenans from tetrasporic thalli were generally higher than those of gametophytic thalli (female gametophytes and non-fructified thalli). In the first case, an explanation for the difference is related to a greater or lesser quantity of carrageenan precursors in samples. As mentioned previously, the presence of mu and nu in native extractions, with a sulphate ester at position 6 of the unit $\alpha$-D-galactose 4-connected (see Fig. 2), prevents the formation of long carrageenan chains promoting the disruption of sequences of repeating units of carrabiose and hence a lower molecular weight (see aqueous extraction in the autoclave of $C$. teedei var. lusitanicus FG in Table 3). Alkaline treatment promoted cyclization of carrageenans, by elimination of the sulphate from sulphate esters on $\mathrm{C}-6$ in the precursors. The reaction of cyclization is carried out by the hydroxide ion $\left(\mathrm{OH}^{-}\right)$, present in the alkaline solutions of $\mathrm{NaOH}$ and $\mathrm{Ca}\left(\mathrm{OH}_{2}\right)$ acts as a catalyst, promoting the formation of bridges of 3,6-anhydrous. In nature, the removal of sulphate and subsequent cyclization of carrageenan is catalyzed by a sulpho-hydrolase (Wong and Craigie, 1977, 1978).

In vivo cyclization of the mu and nu precursors is similar to what occurs in chemical processes involved in the laboratory and/or industrial alkali-extraction (Ciancia et al., 1993). However, contrary to that stated by these authors, cycling derivatives of lambda-carrageenan (e.g. theta-carrageenan) also occurs in native extracted samples. This implies the existence of a cyclization process promoted by appropriate enzymes (see Pereira, Amado, et al., 2009).

Kappa and lambda family carrageenans differ in the quantity and distribution of their sulphate groups (Painter, 1983), thus, in the lambda family, the sulphated esters grouping surrounding the hydroxyl, in C-3 of $\alpha$ unit, acts as shield against polarization or ionization, reducing the cyclization reaction ratio. In practice, the alkaline treatment used is not sufficient to promote transformation of lambda to theta-carrageenan. Industrially, most of the extracted carrageenans from Chondrus and Gigartina tetrasporophytes are mixtures of lambda and theta because, in this case, the cyclization is incomplete and slower than that which occurred during the alkali-treatment of the kappa family carrageenans (Ciancia et al., 1993; Falshaw et al., 2003).

\section{Acknowledgements}

The authors acknowledge financial support from the Portuguese Foundation for Science and Technology - IMAR-CMA (Institute of Marine Research).

\section{References}

Araújo, R., Bárbara, I., Tibaldo, M., Berecibar, E., Tapia, P. D., Pereira, R., et al. (2009). Checklist of benthic marine algae and cyanobacteria of northern Portugal. Botanica Marina, 52(1), 24-46.

Ardré, F. (1970). Contribuition à l'étude des algues marines du Portugal. I. La flore. Portugalia Acta Biologica B, 10(1-4), 1-423. 
Ardré, F. (1971). Contribuition à l'étude des algues marines du Portugal, II. Ecologie et chorologie. Bulletin du Centre d'Etudes de la Recherche Scientifique de Biarritz, $8(3), 359-574$

Ciancia, M., Noseda, M. D., Matulewicz, M. C., \& Cerezo, A. S. (1993). Alkalimodification of carrageenans - Mechanism and kinetics in the kappa-iotaseries, mu-nu-series and lambda-series. Carbohydrate Polymers, 20(2), 95-98.

Falshaw, R., Bixler, H. J., \& Johndro, K. (2003). Structure and performance of commercial kappa-2 carrageenan extracts. Part III. Structure analysis and performance in two dairy applications of extracts from the New Zealand red seaweed, Gigartina atropurpurea. Food Hydrocolloids, 17(2), 129-139.

Guiry, M. D., West, J. A., Kim, D. H., \& Masuda, M. (1984). Reinstatement of the genus Mastocarpus Kutzing (Rhodophyta). Taxon, 33(1), 53-63.

Lewis, J. R. (1964). The ecology of rocky shores. London: English Universities Press Ltd.

Melo, R. A. (1998). Gelidium commercial exploitation: Natural resources and cultivation. Journal of Applied Phycology, 10(3), 303-314.

Múrias, A. (1994). Estudo e caracterização dos povoamentos bentónicos intertidais de substrato rochoso do Norte de Portugal. UP. Porto: Universidade do Porto.

Painter, T. (1983). The polysaccharides London: Academic Press.

Palminha, F. P. (1951). Contribuição para estudo das algas marinhas portuguesas I. Boletim da Sociedade Portuguesa de Ciências Naturais, 2(3), 226-250.

Palminha, F. P. (1971). Exploração e utilização de algas marinhas na plataforma portuguesa e nas ilhas do Arquipélago dos Açores. Junta Nacional do Fomento das Pescas, 7, 25-36.

Pereira, L. (2004). Estudos em macroalgas carragenófitas (Gigartinales, Rhodophyceae) da costa portuguesa - aspectos ecológicos, bioquímicos e citológicos (pp. 293). PhD Thesis, Department of Botany, Faculty of Sciences and Technology, University of Coimbra, Coimbra.

Pereira, L. (2006). Identification of phycocolloids by vibrational spectroscopy. In A. T. Critchley, M. Ohno, \& D. B. Largo (Eds.), World seaweed resources - An authoritative reference system. Wokingham, Berkshire: ETI Information Services Ltd.

Pereira, L., \& Mesquita, J. F. (2003). Carrageenophytes of occidental Portuguese coast: 1-spectroscopic analysis in eight carrageenophytes from Buarcos Bay. Biomolecular Engineering, 20(4-6), 217-222.

Pereira, L., \& Mesquita, J. F. (2004). Population studies and carrageenan properties of Chondracanthus teedei var. lusitanicus (Gigartinaceae, Rhodophyta). Journal of Applied Phycology, 16(5), 369-383.

Pereira, L., Sousa, A., Coelho, H., Amado, A. M., \& Ribeiro-Claro, P. J. A. (2003). Use of FTIR, FT-Raman and ${ }^{13} \mathrm{C}$-NMR spectroscopy for identification of some seaweed phycocolloids. Biomolecular Engineering, 20(4-6), 223-228.

Pereira, L., van de Velde, F., \& Mesquita, J. F. (2007). Cytochemical studies on underutilized carrageenophytes (Gigartinales, Rhodophyta). International Journal of Biology and Biomedical Engineering, 1(1), 1-5.
Pereira, L., Amado, A. M., Critchley, A. T., van de Velde, F., \& Ribeiro-Claro, P. J. A. (2009). Identification of selected seaweed polysaccharides (phycocolloids) by vibrational spectroscopy (FTIR-ATR and FT-Raman). Food Hydrocolloids, 23, 1903-1909. doi:10.1016/j.foodhyd.2008.11.014

Pereira, L. Critchley, A. T. Amado, A. M. \& Ribeiro-Claro, P.J. A. (2009). A comparative analysis of phycocolloids produced by under-utilized versus industrially utilized carrageenophytes (Gigartinales, Rhodophyta). Journal of Applied Phycology, 21, 599-605. doi:10.1007/s10811-009-9447-4

Rudolph, B. (2000). Seaweed products: Red algae of economic significance. In R. E. Martin (Ed.), Marine and Freshwater Products Handbook (pp. 515-529). Lancaster, PA: Technomic Pub. Co.

Santos, R., \& Duarte, P. (1991). Marine plant harvest in Portugal. Journal of Applied Phycology, 3(1), 11-18.

Sousa-Pinto, I. (1998). The seaweed resources of Portugal. In A. T. Critchley, \& M. Ohno (Eds.), Seaweed Resources of the World (pp. 176-184). Yokosuka: Japan International Cooperation Agency.

Sousa-Pinto, I., \& Araújo, R. (2006). The seaweed resources of Portugal. In A. T. Critchley, M. Ohno, \& D. B. Largo (Eds.), World seaweed resources: An authoritative reference system. ETI Information Services Ltd.

van de Velde, F., \& de Ruiter, G. A. (2002). Carrageenan. In E. J. Vandamme, S. D. Baets, \& A. Steinbèuchel (Eds.), Biopolymers v. 6. Polysaccharides II, polysaccharides from eukaryotes (pp. 245-274). Weinheim, Chichester: Wiley-VCH.

van de Velde, F., Peppelman, H. A., Rollema, H. S., \& Tromp, R. H. (2001). On the structure of kappa/iota-hybrid carrageenans. Carbohydrate Research, 331(3), 271-283.

van de Velde, F., Knutsen, S. H., Usov, A. I., Rollema, H. S., \& Cerezo, A. S. (2002). H-1 and C-13 high resolution NMR spectroscopy of carrageenans: Application in research and industry. Trends in Food Science E Technology, 13(3), 73-92.

van de Velde, F., Pereira, L., \& Rollema, H. S. (2004). The revised NMR chemical shift data of carrageenans. Carbohydrate Research, 339(13), 2309-2313.

van de Velde, F., Antipova, A. S., Rollema, H. S., Burova, T. V., Grinberg, N. V., Pereira, L., et al. (2005). The structure of kappa/iota-hybrid carrageenans II. Coil-helix transition as a function of chain composition. Carbohydrate Research, 340(6), 1113-1129.

Wong, K. F., \& Craigie, J. S. (1977). Enzymic conversion of mu to kappa-carrageenan by a sulfohydrolase from Chondrus crispus. Plant Physiology, 59(6), 6-16.

Wong, K. F., \& Craigie, J. S. (1978). Sulfohydrolase activity and carrageenan biosynthesis in Chondrus crispus (Rhodophyceae). Plant Physiology, 61(4), 663-666.

Zinoun, M., \& Cosson, J. (1996). Seasonal variation in growth and carrageenan content of Calliblepharis jubata (Rhodophyceae, Gigartinales) from the Normandy coast, France. Journal of Applied Psychology, 8(1), 29-34. 